\title{
Lectotypification of the name Gymnostachyum canescens (Acanthaceae)
}

\section{Shameer M.C. ${ }^{1 \& 2^{*}}$ and V.K. Sreenivas ${ }^{1}$}

${ }^{1}$ Department of Botany, Sri Vyasa N.S.S. College, Wadakkanchery, Thrissur, Kerala, India

${ }^{2}$ Research and Development Centre, Bharathiar University, Coimbatore, Tamil Nadu, India.

Received: 07-06-2018; Revised: 19-06-2018; Accepted: 28-06-2018

Abstract: The lectotype of Gymnostachyum canescens (Nees) T. Anderson is designated here.

Keywords: Acanthaceae, Gymnostachyum canescens, Lectotype, Western Ghats.

\section{Introduction}

In India, the genus Gymnostachyum Nees (Acanthaceae) is represented by 15 taxa distributed mainly in Western Ghats region (Prabhukumar et al., 2015). While revising the genus Gymnostachyum in India, it is revealed that, the species $G$. canescens (Nees) T. Anderson was published without the designation of type. Therefore, we have scruitinized the protologue and then followed by the herbarium survey, found that $G$. canescens is needed to be typified. The lectotype is designated here according to Art. 9.2 of the ICN (McNeill et al., 2012).

Typification of names

Gymnostachyum canescens (Nees) T. Anderson (1867: 505) Cryptophragmium canescens Nees (1832: 100)

Type (lectotype, designated here): INDIA, Mysore-Carnatic region, G. Thomson s. n., (P, barcode P00719603) [digital images!] Fig. 1.

Residual Syntypes: INDIA, Courtallum, Wight s. n., (P barcode P00719604) [digital images!]

Nomenclatural notes: Nees (1832) proposed the name Cryptophragmium canescens based on heterogenous collections viz. from Mysore-Carnatic region by $\mathrm{G}$. Thomson and Courtallum by Wight. Later, Anderson (1867) transferred the name to the genus Gymnostachyum, as $G$. canescens. During the study, we have traced 2 specimens, which represent the collections mentioned in the protologue (Thomson's and Wight's) with single sheet each. Among the two sheets, the collection housed at P, by Thomson from Mysore-Carnatic region is well preserved and bear flowers and fruits. The Wight's sheet has been traced also from P (P00719604!) but which do not bear any flowers and fruits except few leaves. According to Art. 9.2 of Melbourne Code (McNeill et al., 2012) the specimen collected by

*Corresponding Author:

M.C. Shammer

Department of Botany,

Sri Vyasa N.S.S. College,

Wadakkanchery, Thrissur, Kerala, India

E-mail: scheriyath@gmail.com
Thomson and kept in P (P barcode P00719603 [digital images!]) fits the description, and is preserved very well, which is considered as the best choice and designated here as the lectotype.

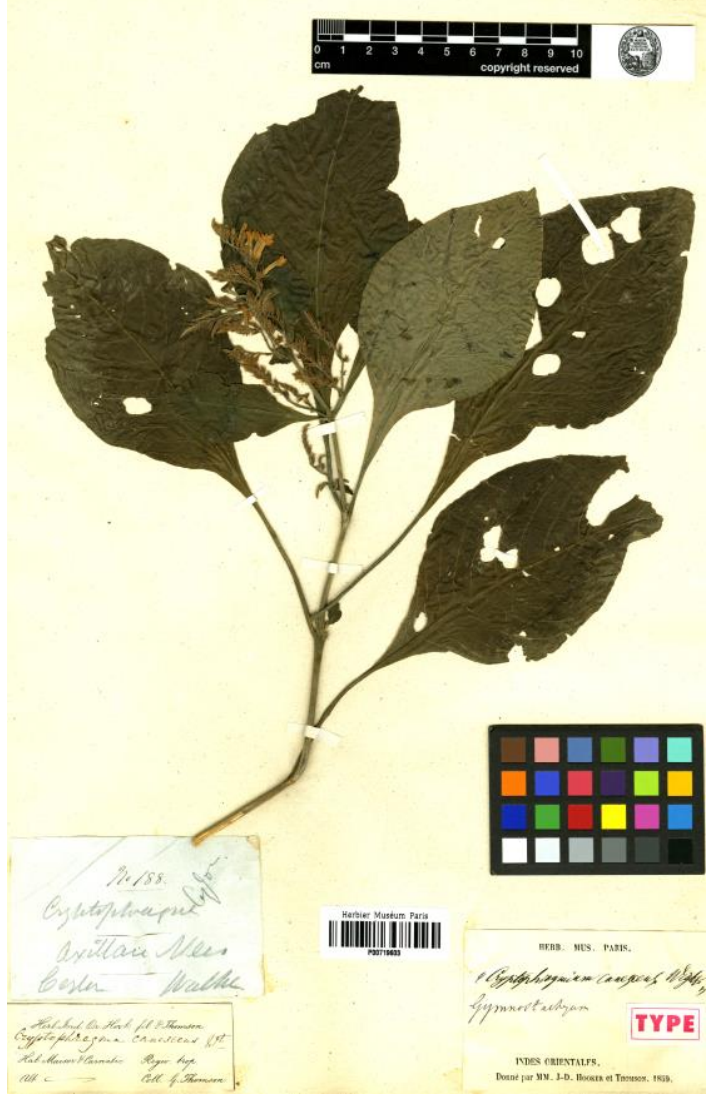

Figure 1.

\section{Acknowledgements}

The authors express their sincere gratitude to the authorities of the Royal Botanic Gardens, Kew for providing the digital images. 


\section{References}

1. Anderson, T. "An Enumeration of the Indian Species of Acanthaceae". Botanical Journal of Linnean Society 7 (1867): 425-526. Print.

2. McNeill, J., F.R. Barrie, W. R. Buck, V. Demoulin, W. Greuter, D.L. Hawksworth, P.S. Herendeen, S. Knapp, K. Marhold, J. Prado, W.F. Prud'Homme Van Reine, G.F. Smith, J. H. Wiersema, and N.J. Turland. "International Code of Nomenclature for algae, fungi, and plants (Melbourne Code) adopted by the Eighteenth International Botanical Congress Melbourne, Australia”. (2012): July 2011. [Regnum Vegetabile 154]. Print
3. Prabhukumar, K.M., B. Indira, V.B. Sreekumar, K.S. Ramya, S. George, K.J. Dantas, and A.D. Suma. "Gymnostachyum warrieranum (Acanthaceae), a new species from Western Ghats of India with morphological and molecular data". Kew Bulletin 70(3) (2015): 1-9. Print.

\section{Cite this article as:}

Shameer M.C. and V.K. Sreenivas. Lectotypification of the name Gymnostachyum canescens (Acanthaceae). Annals of Plant Sciences 7.7 (2018) pp. 2377-2378.

do http://dx.doi.org/10.21746/aps.2018.7.7.2 